\title{
EFFECT OF BINDING MATERIALS, FEEDING RATE AND DIE PROFILE ON AQUATIC PELLETS QUALITY USING RING-DIE PELLETING MACHINE
}

\author{
Radwan, M.I. ${ }^{1}$ and A.M. El Shal ${ }^{2}$
}

\begin{abstract}
$\underline{\text { ABSTRACT }}$
The overall goal of the present study is to investigate the effect of using binding materials, feeding rate and die profile on aquatic pellets quality using ring-die pelleting machine to produce a strong and durable aquatic pelleted feeds with lowest specific energy consumption. Three feed blends containing $30 \%$ protein were formulated with the same concentrate level of each starch, gelatin and molasses of $3 \%$ as a binding material instead of fish meal (FM) along with appropriate concentrate levels of soybean meal, corn flour, mix of vitamin and mix of mineral and pelleted in a ring-die pelleting machine. The ring-die pelleting machine was evaluated under the same concentrate levels of replacement percentage of binding materials in feed formula, feeding rate (70, 100 and $125 \mathrm{~kg} / \mathrm{h}$ ) and two types of forming unit of die profile (1) and die profile (2). Using constant values of die speed of $300 \mathrm{rpm}$, average ration moisture content of $17 \%$ (w.b). The evaluation included machine production rate, pelleting efficiency, specific energy consumption, pellets quality (durability, bulk density) and economical costs of aquatic feed pellets mass. The obtained data showed that, the highest values of machine productivity of 123.96 $\mathrm{kg} / \mathrm{h}$, , lowest specific energy consumption of $19.26 \mathrm{~kW} . \mathrm{h} / \mathrm{Mg}$, the highest values of durability (92.68\%) and pelleting efficiency of $98.67 \%$ were recorded in the case of gelatin as binding material, die profile (1) and feeding rate of $125 \mathrm{~kg} / \mathrm{h}$. but the highest values of pellets bulk density $\left(0.822 \mathrm{~g} / \mathrm{cm}^{3}\right)$ was recorded in the case of molasses as binding material, die profile (1) and feeding rate of $125 \mathrm{~kg} / \mathrm{h}$.
\end{abstract}

\footnotetext{
${ }^{1}$ Researcher, Agric. Eng., Central Lab. for Aquaculture Res., Agric. Res. Cent.., Egypt ${ }^{2}$ Lecturer, Agric. Eng. Dept., Fac. of Agric., Zagazig Univ., Egypt.
} 


\section{INTRODUCTION}

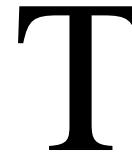
The main goal of pelleted feeds manufacturers and nutrients is to provide a balanced nutritious feeds with a high levels of quality complete or supplemental feed in aquaculture, boost productivity per unit of area, reduce feed wastage and consequently, maintain water quality in either ponds or aquarium in addition to decrease the consumed energy during pelleting operation as well as operational cost. Extrusion agglomeration using a ring die has proved to be a universally acceptable and economic method for compacting any lumpy, long-fibred, powdery, and pasty materials which have not been pre-ground. Therefore, there was a necessity to study the factors affecting the machine performance and pellet quality. Alfalfa pellets have been known to generate dust and fines because of repeated handling and transport. During transport this product loses or gains moister which may affected its quality. Therefore there is a need to manufacture pellets which are not prone to breakage but still can be palatable to the animals. There are many variables which affect the pelleting process. Thus, feed pellet quality depends on many factors: content and leve1 of different ingredients (Wood, 1987) ; fat, minerals and fibre content; particle size (Reece et al., 1986); inclusion of binder and factors related to the process of pelleting; conditioning (Gill, 1993) ; distance between roller and die (Bobohm, 1992) ; hole compression and others. Mash feeds are often subjected to granulation (pelleting) in routine feed manufacturing. The subsequent stages in the pelleting process are meal conditioning, pelleting and drying/cooling. Meal conditioning is a prerequisite for the actual compression of the meal into pellets and can be controlled by its process variables such as temperature, time and moisture level. Proper conditioning, therefore, brings adhesive properties on the surface of meal particles thereby improving pellet quality in terms of a harder pellet or a reduction of fines produced from pellets during additional handling (Skoch et al., 1981). Heffner and Pfost (1973) found a higher degree of gelatinization of feed starch with the use of a smaller diameter of the die-hole. Gelatinization and durability of the pellets were also higher with smaller die-holes. 
However, the ratio of length to diameter was also slightly altered, making it difficult to attribute higher gelatinization percentage to the smaller die diameter. According to Smith (1983), starch may function, among others, as an adhesive or binding agent. Starches used for these purposes have undergone a heat or chemical treatment in which the properties of the native starch are changed. Gelatinizing of starch in the presence of water and heat, in the presence or absence of shear, is the most common way to affect functional properties of starches Fasina et al. (2004) showed that bulk density decreased and particle of pelleted litter increased by increasing the moisture content. The force required to rupture the pellets varied from $350 \mathrm{~N}$ at $6 \%$ moisture to $50 \mathrm{~N}$ at $22 \%$ (w.b.). Ouchiyama and Tanaka (1985), found that main parameter during pelleting is the distance between roller and die (The clearance-size). Often the rollers are set to just touch the die. With increasing clearance-size, initially pellet hardness or durability will increase, thereafter pellet durability and hardness will deteriorate. The main objective of this study is to investigate the effect of using binding materials, feeding rate and die profile on 1) the ring-die pelleting machine parameters including productivity, pelleting efficiency and specific consumed energy 2) pellets quality such as; durability and bulk density.

\section{MATERIALS AND METHODS}

Experiments were carried out in fodder manufacture unit of Central Laboratory for Aquaculture Research in Abbassa, Abou Hammad district, Sharkia Governorate.

\section{1-Experimental ration}

The experimental ration was prepared by a hammer mill, the ration particles fineness were average $1 \mathrm{~mm}$ mixed in forage mixer with about $17 \%$ moisture of total mass moisture content as wet basic ( w.b ). Three ingredient blends were formulated with $30 \%$ protein.

\section{2-The specifications of ring-die pelleting machine}

The tested ring-die pelleting machine was fabricated in United State of America by CPM company to produce fish feed. The construction 
features of the ring-die pelleting machine mainly consists of the following units as shown in Fig.(1).

\section{a- Feeding hopper}

Feeding hopper is the part in which the ration in Table (1) put before conditioning stage .It constructed of steel metal with $3 \mathrm{~mm}$. thickness, $430 \mathrm{~mm}$. length, $340 \mathrm{~mm}$. width and $450 \mathrm{~mm}$. height. Maximum capacity of feeding hopper is about $10 \mathrm{~kg}$. As shown in Fig.(1) there is a gate at the bottom of the hopper to allow ration to flow through it to the vibrator which allow the ration to flow through it to conditioning unit.

Table (1): Ingredients of the experimental diets (on dry matter basis).

\begin{tabular}{|c|c|c|c|}
\hline \multirow{2}{*}{ Ingredients } & \multicolumn{3}{|c|}{ Replacement of binding material in experimental } \\
& rations (\%) \\
\cline { 2 - 4 } & Corn starch & $\begin{array}{c}\text { Gelatinized } \\
\text { starch }\end{array}$ & Molasses \\
\hline Fish meal & 9.50 & 9.50 & 9.50 \\
\hline Soybean meal & 45.10 & 45.10 & 45.10 \\
\hline Corn meal & 19.50 & 19.50 & 19.50 \\
\hline Wheat bran & 18.40 & 18.40 & 18.40 \\
\hline Corn starch (cs) & 3 & 0 & 0 \\
\hline Gelatinized starch (gs) & 0 & 3 & 0 \\
\hline Molasses & 0 & 0 & 3 \\
\hline Cod - liver oil & 1.50 & 1.50 & 1.50 \\
\hline Corn oil & 2.00 & 2.00 & 2.00 \\
\hline premix & 1.00 & 1.00 & 1.00 \\
\hline Total & 100 & 100 & 100 \\
\hline
\end{tabular}

* According to the obtained knowledge from fish feeding research section, central laboratory for aquaculture research, agriculture research center. 


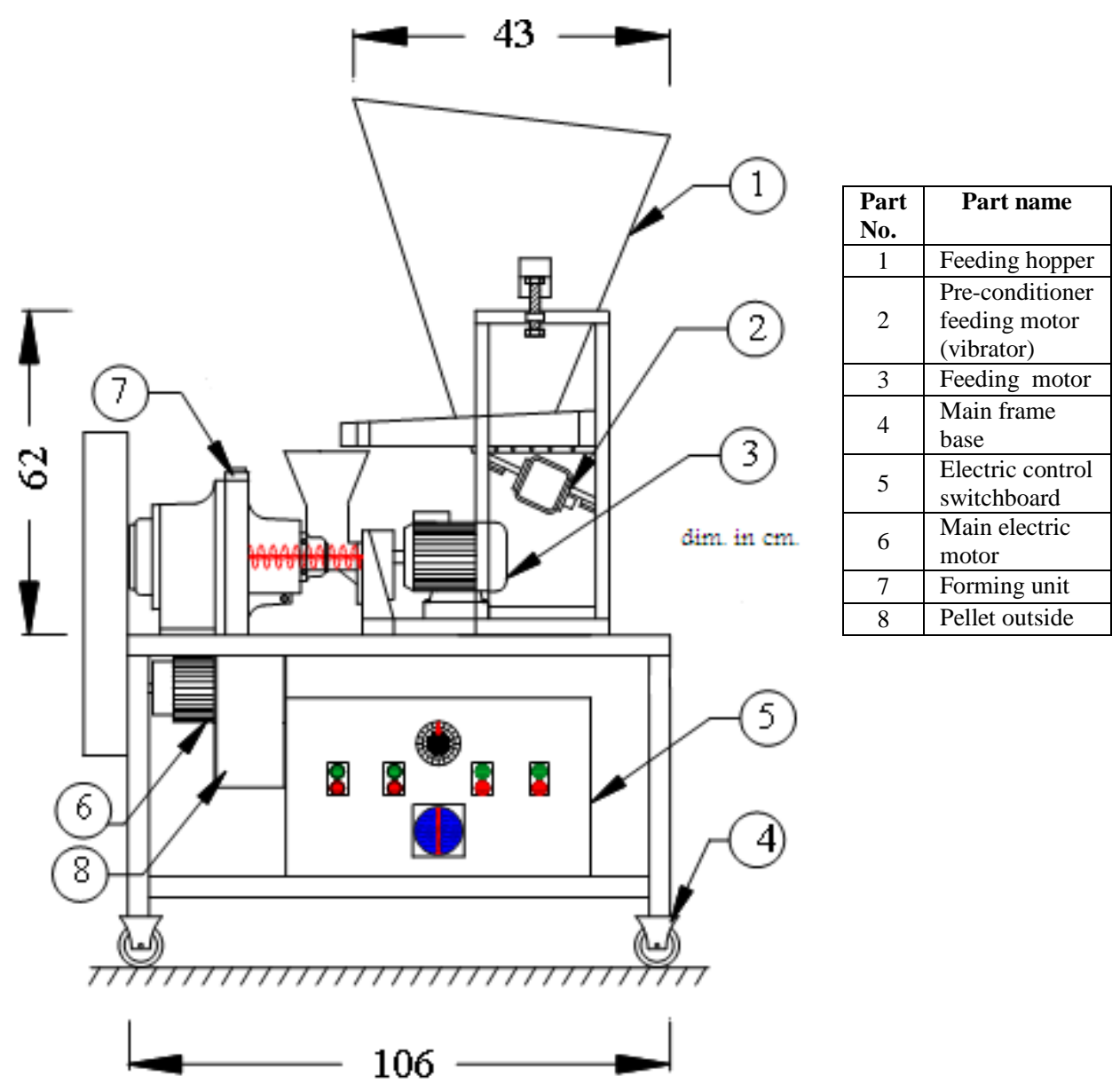

Fig. 1: The ring-die pelleting machine

\section{b- Forming unit}

This unit which is responsible for compressing the ration in the forming zone. It consists of die and roller as shown in Fig.(2) Clearance between the die and roller length is controlled by increasing and decreasing to obtain the optimum of pellet quality and lowest of specific energy consumption. The die speed is $300 \mathrm{rpm}$ and

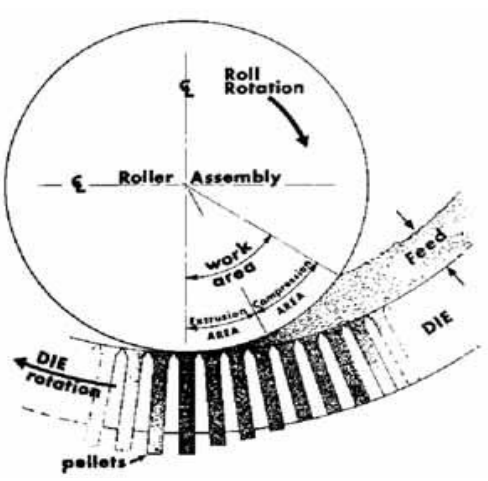

Fig. 2: The forming unit 
each die profile (1) and (2) have some different dimensions shown in Fig. $(3,4)$ and table (2). The die have only one roller it is diameter $85 \mathrm{~mm}$. The surface of the roller has incisions to obtain the optimum of compressed pellet. There are two holes in forming unit. The first hole to receive the ration from feeding screw, the second hole is in the bottom of forming unit to allow the compressed pellet to discharge.

Table (2): Dies profile.

\begin{tabular}{|c|c|c|c|c||}
\hline Die profile & $\begin{array}{c}\text { Die thickness } \\
(\mathbf{m m})\end{array}$ & $\begin{array}{c}\text { Die hole } \\
\text { diameter } \\
\text { (entry) } \\
(\mathbf{m m})\end{array}$ & $\begin{array}{c}\text { Die hole } \\
\text { number }\end{array}$ & $\begin{array}{c}\text { Die hole } \\
\text { diameter } \\
\text { (output) } \\
(\mathbf{m m})\end{array}$ \\
\hline Die profile (1) & 26 & 3.2 & 340 & 3 \\
\hline Die profile (2) & 26 & 4.7 & 187 & 4.5 \\
\hline
\end{tabular}

\section{c- Cutter knife}

Cutter knife was fixed on ring die surface to cut the final product into small parts. It consists of one sharp blade, the obtained pellets length is controlled by increasing and decreasing the clearance between knife and the out-put port.
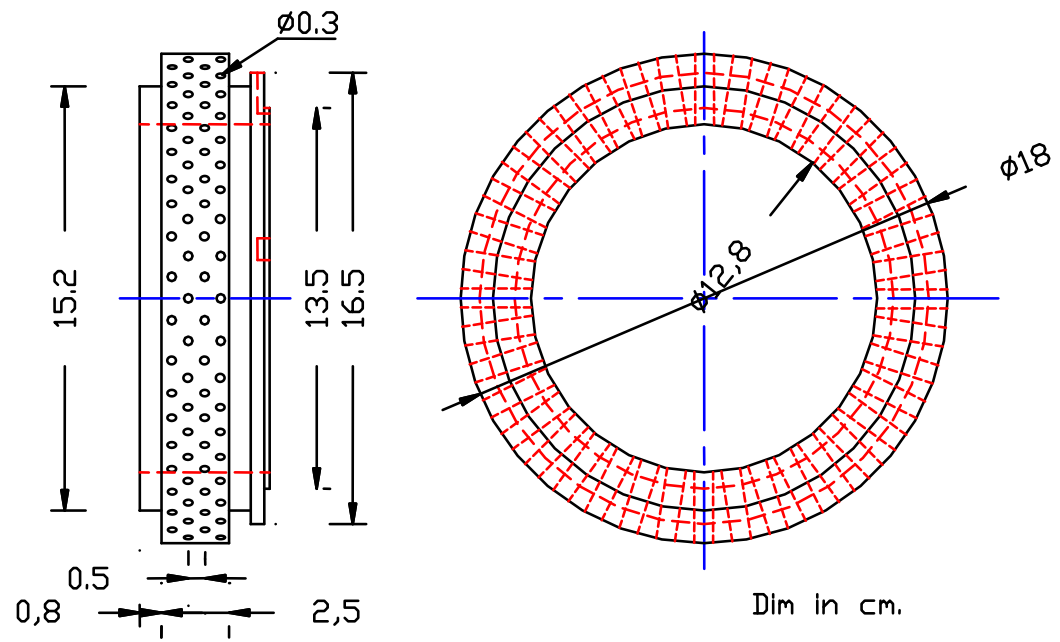

Fig. 3: die profile (1) 


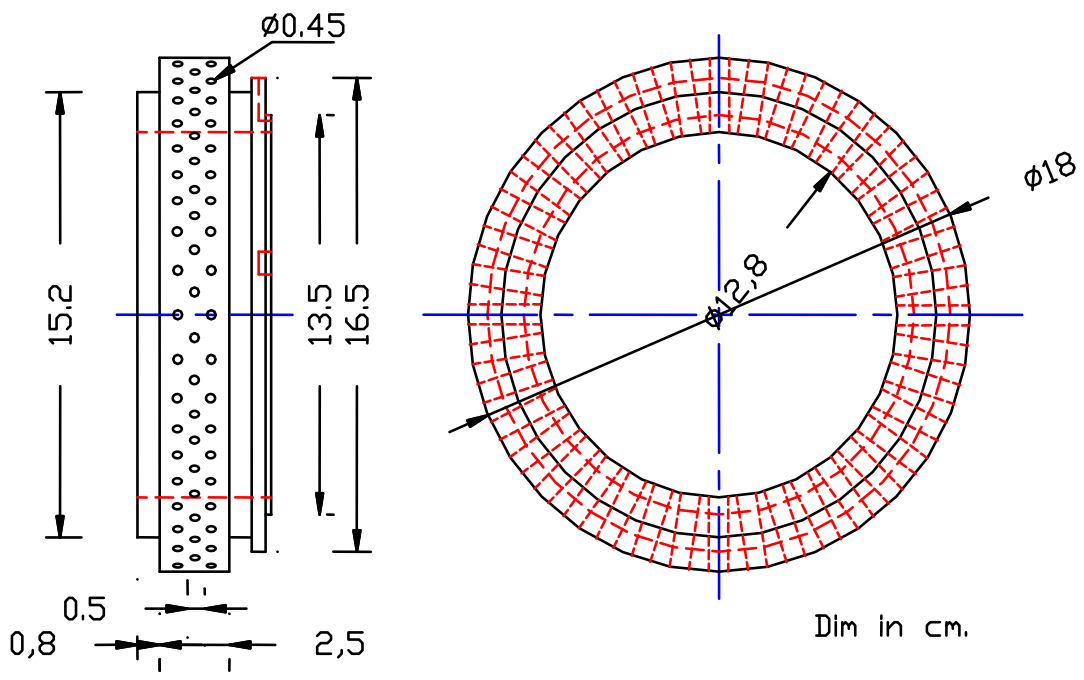

Fig. 4: die profile (2)

\section{d- Power unit:}

The main power unit including motor with rated power $2 \mathrm{~kW}$ at 1400 rpm rotational speed, with 5.4 A. It was used to operate the pelleting machine through reducer pulley and belt. The second motor with rated power $0.45 \mathrm{~kW}$ is the feeding motor, used to operate forming unit.

\section{1-Pelleting machine experiment}

Experiments were conducted to evaluate a ring-die pelleting machine using constant values of roller speed of $300 \mathrm{rpm}$ (motor speed $1400 \mathrm{rpm}$ ) , moisture content $17 \%$ and roller gab $0 \mathrm{~mm}$ to optimize some operating and engineering parameters affecting its performance and pellets quality using binding materials (corn starch, gelatinized starch and molasses) in fish feed formulation, these parameters are

1- Three concentrate levels of different binding materials in the fish feed formula with percentage 3\% (corn starch, gelatinized starch and molasses) were studied.

2-Three levels of feeding rate $(70,100$ and $125 \mathrm{~kg} / \mathrm{h})$ were studied.

3- Two die types (die profile (1) and die profile (2) were studied. 


\section{-Machine performance and pellets quality}

\section{1- Productivity (capacity) kg/h:}

The productivity of the machine was measured as the mass of pellet collected per hour. During the experiments the compressed pellets were collected for every 60 seconds and the productivity was calculated as follows:

Productivity $(\mathrm{kg} / \mathrm{h})=\frac{W_{P}}{T} \times 3.6$

Where $\mathrm{W}_{\mathrm{p}}$ : pellets mass $(\mathrm{g}) . \quad \mathrm{T}$ : consumed time (sec.).

\section{2-Pelleting efficiency}

Pelleting efficiency $(\%)=W_{p} / W m * 100$

Where: $\mathrm{W}_{\mathrm{p}}$ : pellets mass $(\mathrm{g}) . \quad \mathrm{W}_{\mathrm{m}}$ : ration sample mass $(\mathrm{g})$.

\section{3- Pellet durability:}

The durability of pellets was determined according to ASAE standard (1996). Since pellets were sieved on the appropriate sieve to remove fines. A sample mass of about $500 \mathrm{~g}$ placed in the tumbling box device for tumbling up to $10 \mathrm{~min}$, the sample will be removed, sieved and the percent of the whole pellets calculated as follows:

Durability $(\%)=\frac{W a}{W b} \times 100$

Where: Wa: pellets mass after tumbling $(\mathrm{g}) . \quad \mathrm{W}_{\mathrm{b}}$ : pellets mass before tumbling $(\mathrm{g})$

\section{4-Pellets bulk density}

Bulk density $\left(\mathrm{g} / \mathrm{cm}^{3}\right)=\frac{W d}{V d}$

Where: $\mathrm{W}_{\mathrm{d}}$ : pellets sample mass $(\mathrm{g})$.

$\mathrm{V}_{\mathrm{d}}$ : pellets sample volume $\left(\mathrm{cm}^{3}\right)$.

\section{5- Total consumed power}

The consumed power was calculated according to the following equation (Ibrahim, 1982).

Total consumed power, $(k W)=\frac{\sqrt{3} I V \eta \cos \theta}{1000}$ 
Where:

I : Line current strength, Amperes.

$\mathrm{V} \quad$ : Potential difference (Voltage) being equal to $380 \mathrm{~V}$.

$\operatorname{Cos} \theta$ : Power factor (being equal to 0.84).

$\sqrt{3}$ : Coefficient current three phase (being equal 1.73).

$\eta \quad$ : Mechanical efficiency assumed (90\%).

\section{6- Specific consumption energy}

Consumed power $(k W)$

Specific consumption energy $(k W . h / M g)=$

Machine productivity $(\mathrm{Mg} / \mathrm{h})$

\section{RESULTS AND DISCUSSION}

\section{1-Effect of different binding materials, feeding rate and die profile} on machine productivity:

The effect of different binding materials such as starch, gelatin and molasses, feeding rate and die profile on the productivity of the ring-die pelleting machine is shown in Fig. (5). The results showed that there is a clear effect on machine productivity by using gelatin as a binding material in feed formula using die profile (1) and die profile (2). The increase of machine productivity by gelatin as a binding material could be due to the lubricating effect of heat which decrease the friction through the die holes compared to starch and molasses, so the ration quantities which passed through the compressed unit and outputted from the die holes was increased. The feeding rate had clear effect on the productivity of the ring-die pelleting machine. This was expected because the movement of the mixture in die holes increases as the feeding rate was increased which leads to clear increase in mass flow rate resulting in raising productivity. It was also noticed that, the highest production rate of $100.76 \mathrm{~kg} / \mathrm{h}$ at die profile (2) increased to $123.96 \mathrm{~kg} / \mathrm{h}$ at die profile (1).This increase may be due to the increasing of the output area that make the mass flow of ration to get out from die holes at less time. The highest value of machine productivity of $123.96 \mathrm{~kg} / \mathrm{h}$ was obtained at gelatin as a binding material, feeding rate of $125 \mathrm{~kg} / \mathrm{h}$ and die profile (1). 


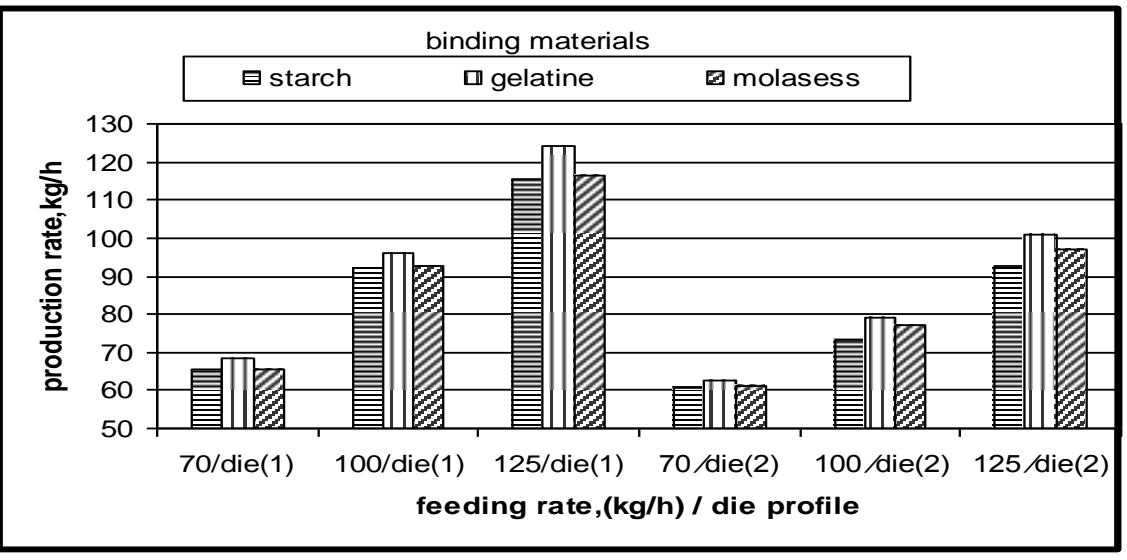

\section{Fig.(5): Effect of different binding materials, feeding rate and die profile on machine productivity .}

\section{2- Effect of different binding materials, feeding rate and die profile on pellets durability:}

Pellets durability is considered one of the most important indicators of pellets quality. The effect of different binding materials such as starch, gelatin and molasses, feeding rate and die profile on the pellet durability is illustrated in Fig.(6). The results showed that little effect on pellet durability by using gelatin as a binding material in feed formula. The amount of heat gelatin which play an important role in the strength of binding of the pellets whereas the amount of solved carbohydrate which caused a hardness in the pellets and increasing the pellets resistance for cracking. Regarding to the influence of the feeding rate, it is observed an increase in pellet durability by increasing feeding rate from 70 to 125 $\mathrm{kg} / \mathrm{h}$. This can be explained that the increase of the pressure inside die zone in forming unit which caused more compaction for the ration granules. It was also noticed that, the pellet durability increases as using die profile (1) instead of die profile (2). This increase of pellet durability could be due to the decrease of output area (the hole) which caused a rising in the pressure inside it, that means a high level of compaction and decreasing air cells between the granules resulting in increasing pellet resistance for cracking. The best value of pellet durability of $92.68 \%$ was 
obtained at gelatin as a binding material, feeding rate of $125 \mathrm{~kg} / \mathrm{h}$ and die profile (1).

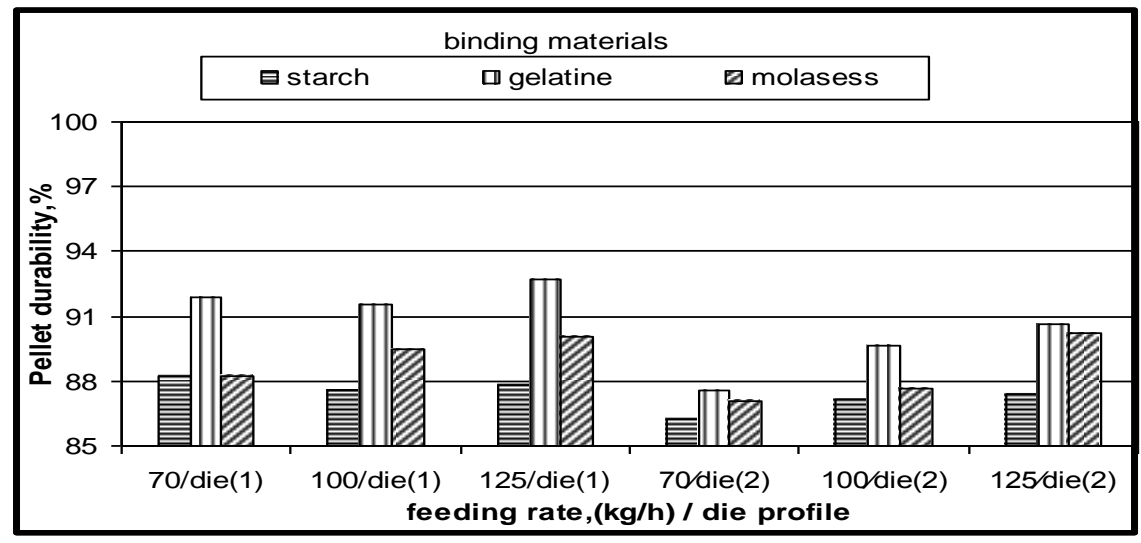

Fig. (6). Effect of different binding materials, feeding rate and die profile on pellet durability.

\section{3- Effect of different binding materials, feeding rate and die profile on pellets bulk density:}

Pellets bulk density is the major aquatic feed pellets quality indicator. The effect of different binding materials such as starch, gelatin and molasses, feeding rate and die profile on the bulk density of pellets is illustrated in the Fig.(7). The variation in binding materials (starch, gelatin and molasses), feeding rate and die profile had different effect on the bulk density of the compressed pellets by the ring-die pelleting machine. The results showed that regarding effect on pellet bulk density by using molasses as a binding material in feed formula because rising of molasses viscosity, which filled the gabs between granules of pellet so, increased the weight of pellets resulting in increasing bulk density. Regarding to the influence of the feeding rate, it is observed an increase in bulk density by increasing the feeding rate. It is obvious that increasing feeding rate will increase the pressure inside the die zone during pelleting process, so high compaction occurs when the mix inside compression zone. The results showed that pellets bulk density increases as using die profile (1) instead of die profile (2). Because the using of die profile (2) will reduce the binding strength among particles by compressing ration. The best values of pellet bulk density of $0.822 \mathrm{~g} / \mathrm{cm}^{3}$ 
was obtained at molasses as a binding material, feeding rate of $125 \mathrm{~kg} / \mathrm{h}$ and die profile (1).

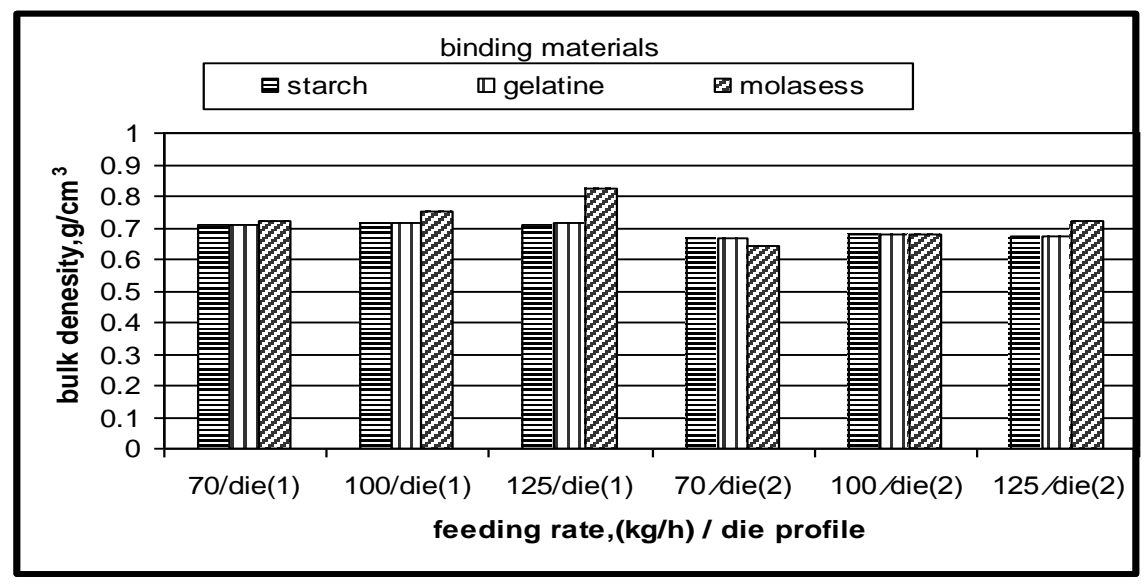

Fig.(7) Effect of different binding materials, feeding rate and die profile on Pellets bulk density.

\section{4- Effect of different binding materials, feeding rate and die profile}

\section{on pelleting efficiency:}

Pelleting efficiency is an important indicator to the percentage of the coming out product as pellets shape not as mash or broken shape. The effect of different binding materials such as starch, gelatin and molasses, feeding rate and die profile on pelleting efficiency is displayed in the Fig.(8). Regarding to the influence of binding materials on pelleting efficiency, the results showed that the pelleting efficiency of the compressed pellets in the ring-die pelleting machine increased by using gelatin as a binding material in feed formula. .This was expected because the lubricant effect of gelatin in the ration leads to increase binding and mass flow of the compressed material which resulting in increasing pelleting efficiency. The obtained results indicate that, as the feeding rate in ring die pelleting machine increased, the compressed force to move the compacted mixture in die holes increased which leads to get out the mixture through die holes caused pellets deformation and increasing in machine productivity. Looking to using die profile (1) instead of die profile (2) on pelleting efficiency, it noticed that the pelleting efficiency of the compressed pellets in the ring-die pelleting machine increased as the die profile (1) was used. The highest value of pelleting efficiency of 
98.67\% was obtained at gelatin as a binding material, feeding rate of 125 $\mathrm{kg} / \mathrm{h}$ and die profile (1).

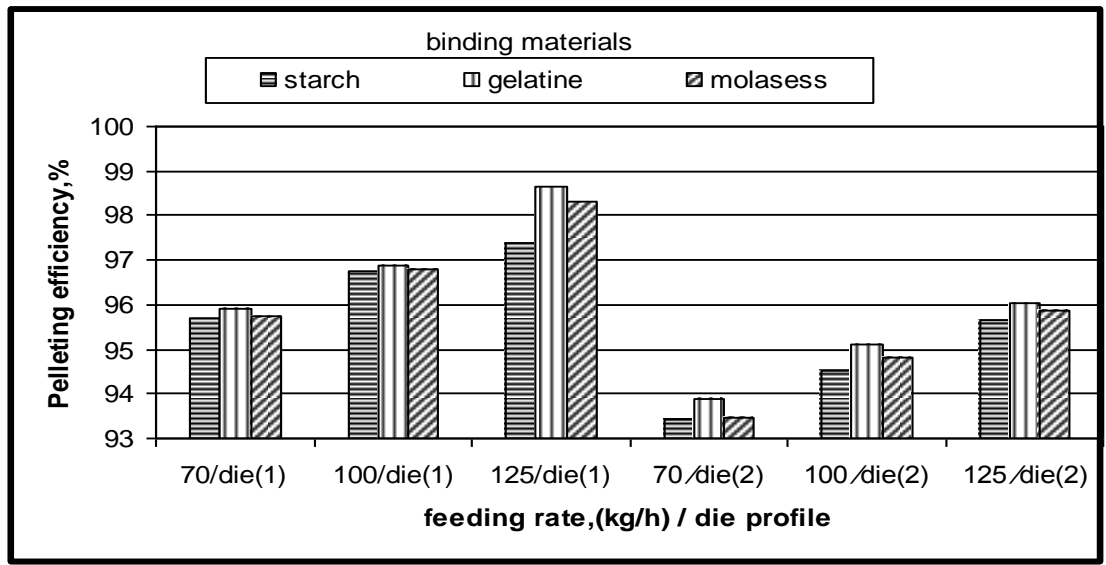

Fig.(8). Effect of different binding materials, feeding rate and die profile on pelleting efficiency.

\section{5- Effect of different binding materials, feeding rate and die profile} on specific energy consumption:

The aquatic feed pellets energy requirements depends theoretically on consumed power and production rate by the practically effect of the different operating parameters such as; different binding materials (starch, gelatin and molasses), feeding rate and die profile as illustrated in Fig.(9), the specific energy consumption decreases by using gelatin as a binding material this decrease in energy requirements could be attributed to the increasing in the production rate in the same time unit more than the increase of power consumed during pelleting process. The obtained results showed that, as the feeding rate increased, sharply increase in production rate with high load on the machine motor was occurred, that is mean high power consumption with high productivity at the same time in pelleting process. It was also noticed that, the lowest energy requirements of $32.09 \mathrm{~kW} \cdot \mathrm{h} / \mathrm{Mg}$ at die profile (2) decreased to $19.26 \mathrm{~kW} . \mathrm{h} / \mathrm{Mg}$ at die profile (1).This increase may be due to the increasing of the output area that make the mass flow of ration to get out from die holes at less time with low load on the machine motor was occurred. The lowest value of specific energy consumption of 19.26 
$\mathrm{kW} . \mathrm{h} / \mathrm{Mg}$ was obtained at gelatin as a binding material, feeding rate of $125 \mathrm{~kg} / \mathrm{h}$ and die profile (1).

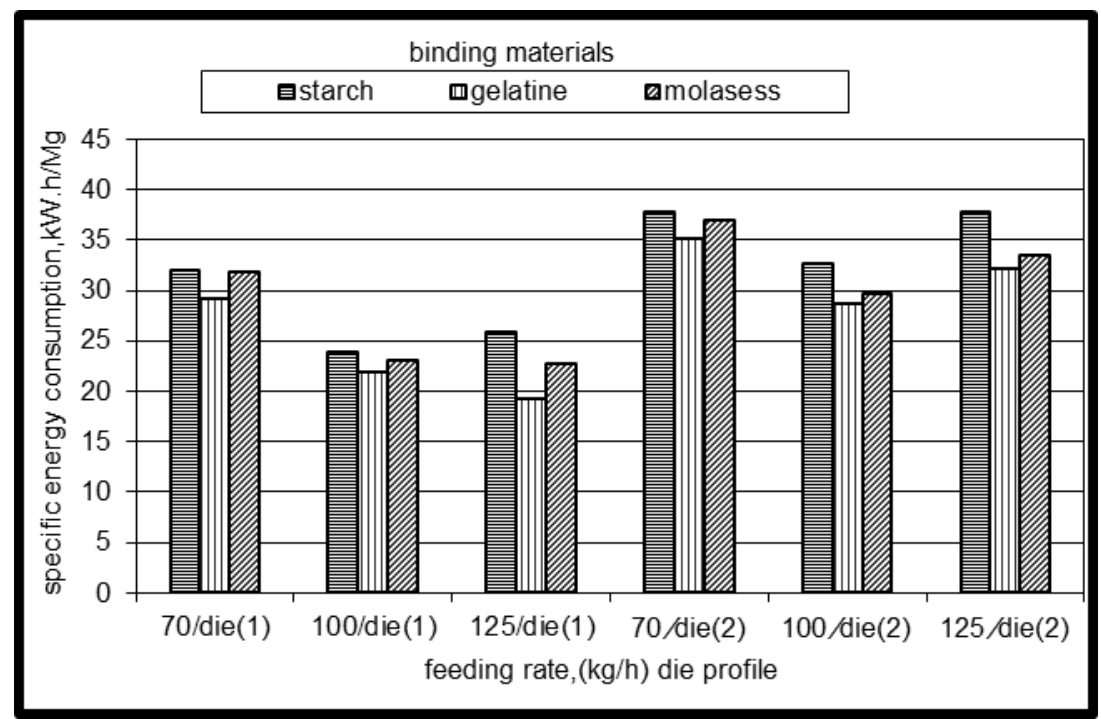

Fig.(9) Effect of different binding materials, feeding rate and die profile on specific energy consumption .

\section{CONCLUSION}

From this investigation, it is recommended to operate the ring-die pelleting machine with the effect of different binding materials such as starch, gelatin and molasses, feeding rate and die profile to achieve the highest values of machine productivity of $123.96 \mathrm{~kg} / \mathrm{h}$, lowest specific energy consumption of $19.26 \mathrm{~kW} \cdot \mathrm{h} / \mathrm{Mg}$, the highest values of durability (92.68\%) were recorded in the case of gelatin as binding material, die profile (1) and feeding rate of $125 \mathrm{~kg} / \mathrm{h}$. but the highest values of pelleting efficiency of $98.67 \%$ and pellets bulk density $\left(0.822 \mathrm{~g} / \mathrm{cm}^{3}\right)$ were recorded in the case of molasses as binding material, die profile (1) and feeding rate of $125 \mathrm{~kg} / \mathrm{h}$.

\section{REFERENCES}

ASAE. 1996. American society of Agricultural Engineers StandardsEngineering practices, and Data, ASAE standard book . 
Bobohm, K-F., 1992. Adjustable roll gap. Benefits to energy demand throughout and pellet durability. Feed International. March, pp. 3035 .

Fasina,O.O, W.Wood, F.yucheng and M. German. 2004. Physical characteristics of Pellets from poultry litter. An ASAE/CSAE Annual International Meeting. Ottawa, Ontario, Canada, 1- 4 August. Paper No. 046005.

Gill. C., 1993. Chemistry for high quality pellets. Or refining the role of binders. Feed International, March, pp.10-11.

Heffner, L.E. and H.B . Pfost. 1973. Gelatinization during pelleting. Feedstuffs,45(23):32-33.

Ibrahim, M. K. 1982. Wet milling of wheat grain. M. Sc. Thesis, Faculty of Agric., Mansoura Univ.,Egypt.

Ouchiyama, N. and T. Tanaka 1985. Kinetic analysis of the compaction process of a pellet in granulation. $4^{\text {th }}$ International Symposium on Agglomeration, Toronto, Canada, pp. 635-641.

Reece, F.N., Lott, B.D. and Deaton, J.W., 1986. Effects of environmental temperature and corn particle size on response of broilers to pelleted feed. Poultry Sci., 65: 636-641.

Skoch, E.R.,K.C. Behnke., C.W. Deyoe., and S.F. Binder. 1981. The effect of steam conditioning rate on the pelleting process. Anim. Feed sci. Tech. $6: 83$.

Smith, P.S., 1983. Food starches and their uses. In: D.L. Downing (Editor), Gum and Starch Technology Eighteenth Annual Symposium. New York State Agricultural Experiment Station, Geneva, pp. 1-9.

Wood, J.F., 1987. The functional properties of feed raw materials and their effect on the production and quality of feed pellets. Anim. Feed Sci. Technol., 18: 1-17. 


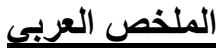

\section{تأثير مواد الربط ومعدل التفذية ومواصفات الداى على جودة أعلاف الأسماك المصبعة باستخدام آلة التصبيع الحلقية التية}

\section{محمد السيد اسماعيل ' أحمد محمد الشال؟}

الهدف الرئيسي لهذه الدراسة هو تقييم أداء آلة تصبيع أعلاف الأسماك ذات المشكل الحلقى لإنتاج إصبعيات علف علي درجة عالية من القوة و المتانة باقل طاقة مستهلكة من خلال در اسة الته بعض عو امل التشغيل التي تؤثر علي اداء الآلة وصفات الجودة للأعلاف. وتم تقييم الآلة من ون

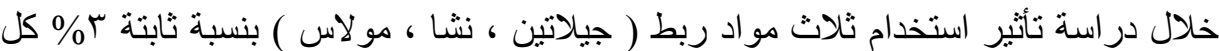

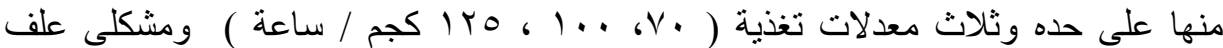

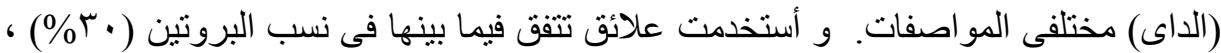
ونسب محددة من فول الصويا، الذرة،وخليط من الفيتامينات و المعادن وتم تصبيعها باستخدام آلة التصبيع الحلقية. وذلك لمعرفة تأثيرمو اد الربط المختلفة و العوامل السابقة على قياسات أداء

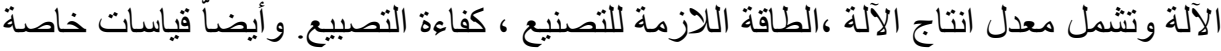

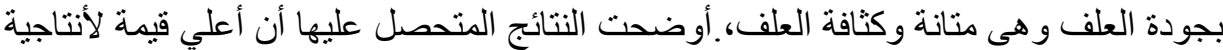

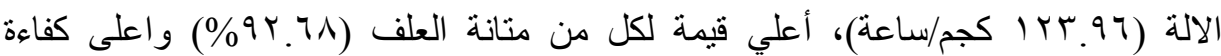

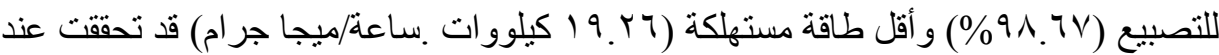

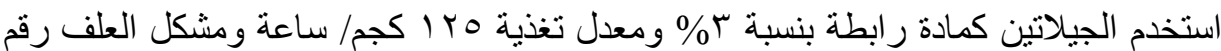

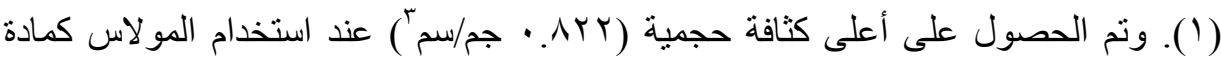

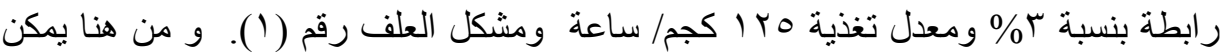

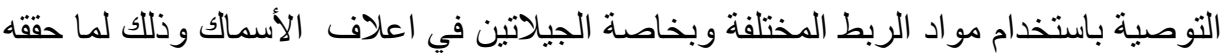

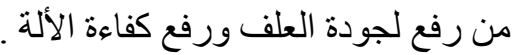

\footnotetext{
'باحث بالمعمل المركزي لبحوث الثروة السمكية ـ مركز البحوث الزراعية ـ مصر.

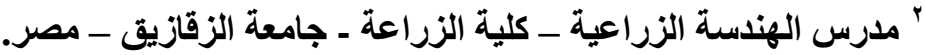

